\title{
THE EFFECT OF PHOSPHORUS AND ZINC DOSES ON YIELD AND YIELD COMPONENTS OF BEANS (PHASEOLUS VULGARIS L.) IN VAN-GEVAŞ, TURKEY
}

\author{
BILDIRİCI, N. ${ }^{*}-$ ORAL, E. ${ }^{2}$ \\ ${ }^{1}$ Yüzüncü Yıl University, Gevaş Vocational School of Higher Education, Department of Plant \\ and Animal Production, Gevaş, Van, Turkey \\ ${ }^{2}$ Department of Field Crops, Faculty of Agriculture, Yüzüncü Yll University, 65080 Van, Turkey \\ ${ }^{*}$ Corresponding author \\ (e-mail: numanbildirici@gmail.com; phone: +90-539-427-3208)
}

(Received 25 Jun 2019; accepted $25^{\text {th }}$ Oct 2019)

\begin{abstract}
This research was carried out in Van-Gevaş in 2015 and 2016 with three replications according to the Divided Parcel Trial Design that was divided into random blocks. The experiment involved 2 bean varieties (Aras-98 and Seker-90) x 4 phosphorus dose $\left(0.0,40.0,60.0\right.$ and $\left.80.0 \mathrm{~kg} \mathrm{ha}^{-1}\right) \times 4$ zinc dose $(0.0,10.0,25.0$ and $\left.50.0 \mathrm{~kg} \mathrm{ha}^{-1}\right) \times 3$ repetition $=72$ parcels were planned and examined. In the experiment, 4 different phosphorus $(\mathrm{P})$ doses were applied to the subparcels as TSP (P2O5) fertilizer. and to gold sub-parcels 4 different zinc (Zn) doses were applied as zinc sulfate $(\mathrm{ZnS04.7H20)}$ fertilizer. Two bean varieties used in the study on the effect of phosphorus and zinc doses on plant height $(\mathrm{cm})$, the number of pods per plant (units of plant ${ }^{-1}$ ), number of branches $\left(\right.$ plant $\left.{ }^{-1}\right)$, seed yield $\left(\mathrm{kg} \mathrm{ha}^{-1}\right)$, harvest index $(\%)$ and the effect of protein $(\%)$ on grain was also investigated. According to the results obtained in 2015 and 2016, the highest grain yield was obtained from Sugar90 beans. In the first year, the highest grain yield was obtained from $3380.00 \mathrm{~kg} \mathrm{ha}^{-1}$ and $40.0 \mathrm{~kg} \mathrm{ha}^{-1}$ phosphorus and $10.0 \mathrm{~kg} \mathrm{ha}^{-1}$ zinc, while in the second year $4250.70 \mathrm{~kg} \mathrm{ha}^{-1}$ was obtained in the same phosphorus and zinc dose. As a result, it has been determined that due to degradation in the phosphorus balance in soil, the efficiency of utilization of zinc in plants affects the yield and quality characteristics.
\end{abstract}

Keywords: bean, number pods, interaction, grain yield

\section{Introduction}

For many thousands of years, legume grains have had a very important place in human nutrition. In cases where animal proteins cannot be provided in suffiecient amount, the deficiencies are met from these plants (Adak, 2014). These plants are rich in vitamins and also minerals such as iron, phosphorus, calcium and potassium, as well as dietary fibers (Pekşen and Artık, 2005). It form in nutrition programs together with cereals a very good group (McPhee and Muehlbauer, 2002). Especially together with high lysin content, cholesterol rates are very low. In human nutrition, edible grain legumes contain $22 \%$ of proteins and $7 \%$ of carbohydrates. $18-31.6 \%$ of the leguminous protein is an important and inexpensive source for solving nutritional problems in the body (Adak et al., 2010; Altunkaynak, 2018). In terms of cultivation and production in the world, this is an important genus in the family of beans. Dry and fresh consumption is common. Around 29 million hectares of land is cultivated in the world. The total production amount is 23 million tons and the yield per hectare is $8000.00 \mathrm{~kg}$ (FAO, 2015). In our country, bean cultivation area is 848 thousand ha, 220 thousand tons production and $2590.00 \mathrm{~kg} \mathrm{ha}^{-1}$ yield is obtained (TÜİK, 2018).

Cultivation, irrigation, fertilization and harvesting are very important in bean production. Fertilization has an important place in these cultural applications. The fact that they fix the free nitrogen of air due to the rhizobium bacteria found in the roots of 
legumes reduces their need for nitrogenous fertilizers. In this case, in the case of deficiencies such as phosphorus and zinc, it increases the importance of the nutritional elements affecting other yield parameters, in particular efficiency. In terms of legumes, phosphorus is an important macro element. This need must be eliminated by fertilization with sowing (Togay and Anlarsal, 2008). The greatest benefit of phosphorous fertilizers is the increase in the quality of the grain and the availability of nitrogen by increasing nodulation and nitrogenase activity (Arıŏlu, 1989).

Another important plant nutrient is zinc, while various enzymes operating in the plant are the building blocks of some hormones in tissue development, the deficiency of zinc leads to the decrease of tryptophan hormone level and protein synthesis is disrupted. In addition, free amino acid accumulation in plants adversely affects grain quality (Yalçın and Usta, 1990).

The height of elements such as phosphorus and zinc in the soil does not always mean that they will be taken and used by plants. In soil, $\mathrm{pH}$, salinity and the amount of other elements are important factors affecting plants. As a result, deficiencies in plants cause significant reductions in yield and quality (Togay and Anlarsal, 2008).

With this study, it was aimed to determine the effect of phosphorus and zinc fertilizers on yield and yield components of beans grown in our region, and as well as to investigate the interactions between $\mathrm{P}$ and $\mathrm{Zn}$ micronutrients.

\section{Materials and Methods}

The research was conducted in Van-Gevaş District $\left(38.2978^{\circ} \mathrm{N}, 43.1055^{\circ} \mathrm{E}\right)$ between the years of 2015-2016 (Figure 1). In the experiment, two bean varieties (Aras-98 and Şeker-90) were used as plant material. The varieties are registered at the East Anatolian Agricultural Research Institute are white and coarse in color (Şehriali, 1988). Climate data for the years of research and the average for many years are given in Table 1.

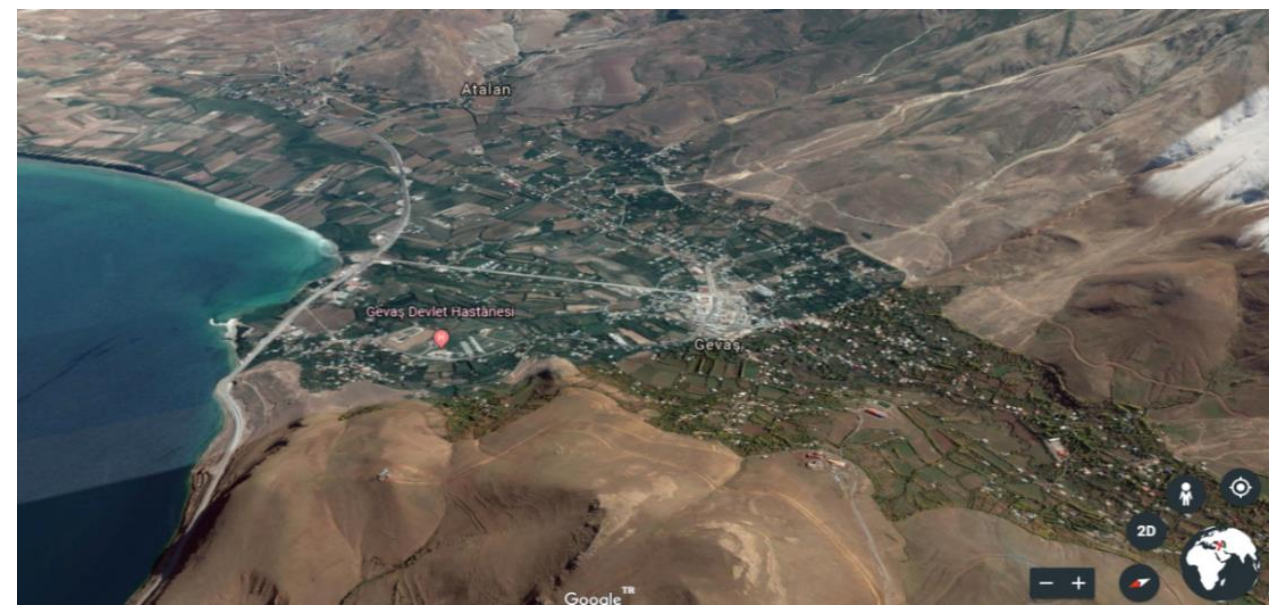

Figure 1. Place of trial (Van-Gevaş)

The total amount of precipitation during the period from May to September in 2015, when the experiment was conducted, was $43.6 \mathrm{~mm}$. In 2016, it was observed that this amount was more than 2015 with $73.3 \mathrm{~mm}$. The average temperature was $18.5^{\circ} \mathrm{C}$ in the 
first year. This value was measured as $17.9^{\circ} \mathrm{C}$ in the second year of the experiment. The average humidity was lower in the first year (42.4\%) than in the second year (50.5\%).

Table 1. Experimental climate data*

\begin{tabular}{|c|c|c|c|c|c|c|c|c|c|c|}
\hline \multicolumn{6}{|c|}{2015 year } & \multicolumn{5}{|c|}{2016 year } \\
\hline \multirow{2}{*}{ Months } & \multicolumn{3}{|c|}{ Temperature $\left({ }^{\circ} \mathrm{C}\right)$} & \multirow{2}{*}{$\begin{array}{l}\text { Cover. } \\
\text { Moisture } \\
(\%)\end{array}$} & \multirow{2}{*}{$\begin{array}{l}\text { Rains } \\
(\mathrm{mm})\end{array}$} & \multicolumn{3}{|c|}{ Temperature $\left({ }^{\circ} \mathrm{C}\right)$} & \multirow{2}{*}{$\begin{array}{c}\text { Cover. } \\
\text { Moisture } \\
(\%)\end{array}$} & \multirow{2}{*}{$\begin{array}{l}\text { Rains } \\
(\mathrm{mm})\end{array}$} \\
\hline & Min & Max & Avg. & & & Min & Max & Ave. & & \\
\hline May & 8.6 & 27.5 & 14.4 & 54.7 & 31.6 & 6.5 & 24.3 & 13.6 & 62.3 & 48.7 \\
\hline June & 13.0 & 34.1 & 18.1 & 39.0 & 11.2 & 12.0 & 34.5 & 18.0 & 56.0 & 15.0 \\
\hline July & 18.0 & 37.9 & 21.7 & 39.2 & - & 17.3 & 37.2 & 20.7 & 46.7 & 3.2 \\
\hline August & 17.1 & 36.4 & 21.5 & 38.7 & 0.8 & 17.5 & 35.9 & 21.1 & 42.0 & 1.8 \\
\hline September & 13.8 & 32.0 & 16.9 & 40.4 & - & 13.4 & 30.4 & 16.2 & 45.3 & 4.6 \\
\hline Average & 14.1 & 33.6 & 18.5 & 42.4 & - & 13.3 & 32.5 & 17.9 & 50.5 & - \\
\hline Total & & & & & 43.6 & & & & & 73.3 \\
\hline
\end{tabular}

* Van Regional Directorate of Meteorology Records, 2017

Soil samples were taken from the $0-20 \mathrm{~cm}$ depth of the soils belonging to the experimental site and analyzed physically and chemically (Table 2).

Table 2. Some chemical properties of experimental soils at a depth of $0-30 \mathrm{~cm}^{*}$

\begin{tabular}{c|c|c|c|c|c|c|c|c}
\hline \multirow{2}{*}{ Years } & Texture & Total Salt & $\mathrm{pH}$ & Calcanty & $\begin{array}{c}\text { Available K } \\
\left(\mathrm{K}_{2} \mathrm{O}\right)\end{array}$ & $\begin{array}{c}\text { Available P } \\
\left(\mathrm{P}_{2} \mathrm{O}_{5}\right)\end{array}$ & $\begin{array}{c}\text { Organic } \\
\text { matter }\end{array}$ & Available Zn \\
\cline { 3 - 9 } & $(\%)$ & & $(\%)$ & $\left(\mathrm{kg} \mathrm{da}^{-1}\right)$ & $\left(\mathrm{kg} \mathrm{da}^{-1}\right)$ & $(\%)$ & $\left(\mathrm{kg} \mathrm{da}^{-1}\right)$ \\
\hline 2015 & $\begin{array}{c}\text { Sandy- } \\
\text { Loam-Clay } \\
\text { Sandy- }\end{array}$ & 0.044 & 7.6 & 8.06 & 51.3 & 2.76 & 2.32 & $0.286($ Poor) \\
\hline
\end{tabular}

*Van Commodity Exchange was conducted in soil analysis laboratories, 2015

The experimental soils are slightly alkaline and the organic matter levels are moderate. It was found that the soil was low in lime, poor in phosphorus and zinc and rich in potassium.

The research was established according to the experimental design of Divided Parcels Divided into Randomized Blocks with 3 replications. The trial area, which was driven deeply in the last spring, was completed in April with a second surface version and disc harrow. Seed planting was carried out in the first week of May, in 5 rows per parcel. The distance between the rows in the parcels was $40 \mathrm{~cm}$. The area of a parcel was $2.0 \mathrm{~m} \times 4.0 \mathrm{~m}=8 \mathrm{~m}^{2}$. In the study, the varieties in the main parcels were Aras-98 and Seker-90, phosphorus (18-19\% $\left.\mathrm{P}_{2} \mathrm{O}_{5}\right)$ doses in sub-parcels and zinc $(\mathrm{Zn})$ sulphate doses $\left(\mathrm{ZnSO}_{4} .7 \mathrm{H}_{2} 0\right)$ were applied to the six parcels in the same test design. The amount of seed to be taken into the parcel was determined to be 45 seeds per $\mathrm{m}^{2} 21 \%$ Ammonium Sulphate $(\mathrm{NH} 4)_{2} \mathrm{SO}_{4}$ fertilizer was placed in the soil with $20.00 \mathrm{~kg}$ of pure nitrogen per hectare evenly to each parcel. Trial parcels; 1 The first foliation period, 2 with branching, 1 before flowering, 1 flowering period, and 1 bean binding period in including was irrigated 6 times in total. (Engin, 1989). In this study, the effect of increasing Zinc ( $\mathrm{Zn})$ and Phosphorus $(\mathrm{P})$ doses on plant height, number of pods per plant, grain yield, harvest index (Harvest index $=$ Grain / Plant stalk ratio), thousand seed weight and protein ratio in two bean varieties were investigated. In the study, two bean varieties were treated in 4 different doses $\left(0.0,10.0,25.0,50.0 \mathrm{~kg} \mathrm{ha}^{-1}\right)$ in the form of $\mathrm{Zinc}^{\mathrm{ZnSO}} \mathrm{Zn}_{4} 7 \mathrm{H}_{2} \mathrm{O}$ and in 4 different doses (0.0 (control), 40.0, 60.0, 80.0, $\mathrm{kg} \mathrm{ha}^{-1}$ ) in the form of phosphorus $\mathrm{P}_{2} \mathrm{O}_{5}$. Each row of 5 parcels on each side of each row and $50 \mathrm{~cm}$ within the row of plants in the row 
as the edge of the effect was excluded from the observation (Ceylan and Sepetoğlu, 1979). All observations were made on an area of $1.2 \mathrm{~m} \mathrm{x} 3 \mathrm{~m}=3.6 \mathrm{~m}^{2}$. The data obtained after trial in terms of yield and yield components were used in determining the differences of split parcel design with the variance analysis method. In the determination of different groups Duncan (5\%) multiple comparison test was utilized with Costata and Mstatc software (Düzgüneş et al., 1987).

\section{Results}

\section{Plant Height (cm)}

According to the data obtained at the end of the research in 2015, the interactions of year, variety, phosphorus, zinc doses, variety $\mathrm{x}$ phosphorus, variety $\mathrm{x}$ zinc, variety $\mathrm{x}$ phosphorus and variety $\mathrm{x}$ phosphorus $\mathrm{x}$ zinc doses were significant and phosphorus $\mathrm{x}$ zinc interactions were not statistically significant. In 2016, other differences between plant height averages were significant (Table 3).

Table 3. Bean varieties in the groups and averages related to the height of the plant*

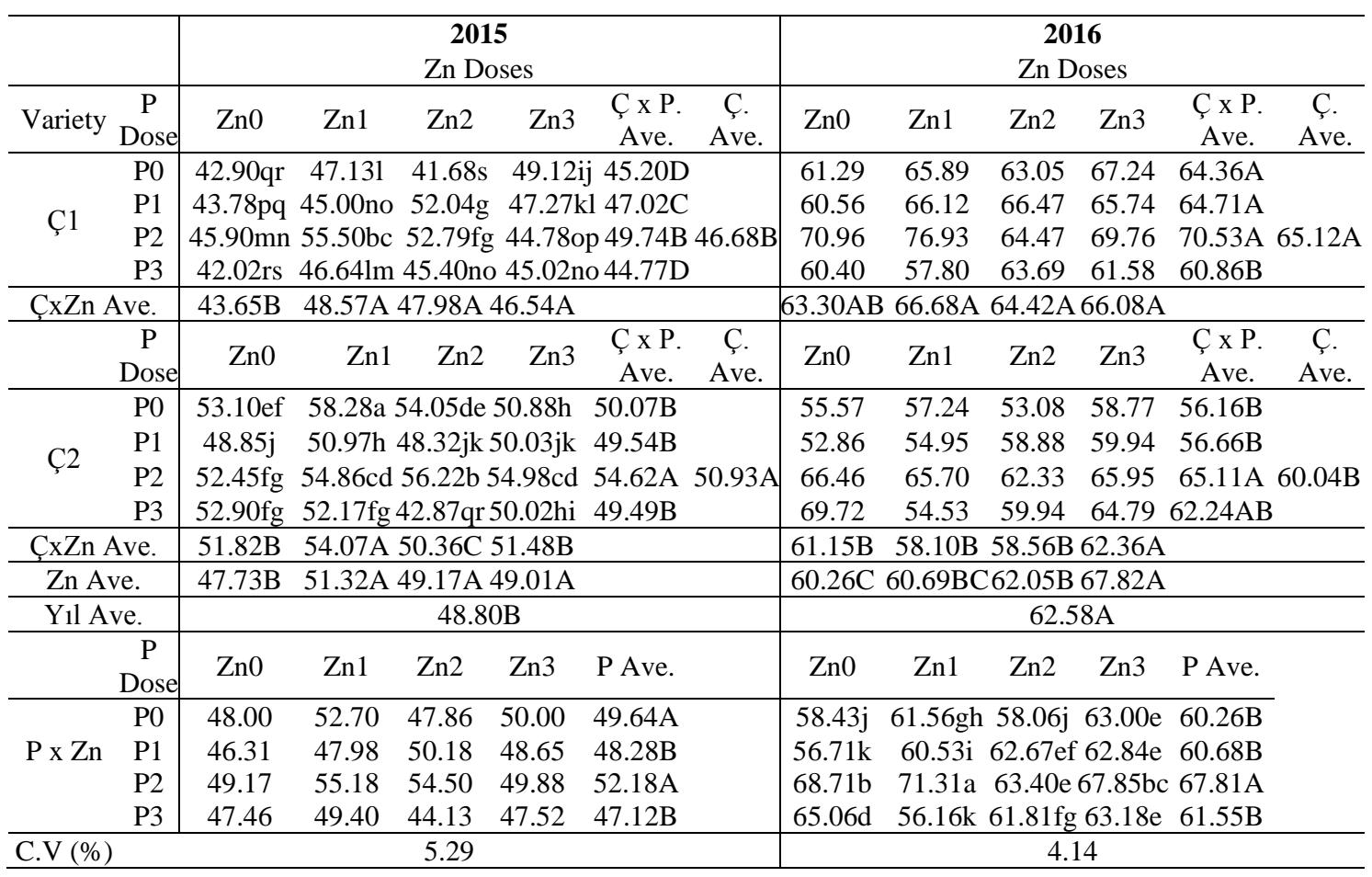

*The difference between the averages indicated with the same letters is not significant at 5\%; C.VCoefficient of variation. Zn- Zinc Dose; Ç1- Aras-98; Ç2-Sugar-90; P-Phosphorus doses; Ave.Average; Z x Zn- Variety x Zinc Dose Interaction; P x Zn- Phosphorus x Zinc Doses Interaction

According to the data obtained at the end of the experiment; In 2015 and 2016, the average plant height was $46.68-65.12 \mathrm{~cm}$ with Aras-98 cultivar, while the Sugar-90 variety was higher with $50.93-60.04 \mathrm{~cm}$. The plant height values obtained from the Seker-90 variety in both years of the experiment were found to be higher than that of the Aras-98 variety (Table 3).

According to the data obtained, average plant height values obtained from different phosphorus doses ranged from $54.62-44.77 \mathrm{~cm}$ in 2015 and from $70.53-56.16 \mathrm{~cm}$ in 2016. In 
the first year of the experiment, the highest plant height $(54.62 \mathrm{~cm})$ was obtained in Sugar-90 from $60 \mathrm{~kg} \mathrm{ha}^{-1}$ phosphorus dose. The lowest plant height value was determined at a dose of 0 (control) applied to Aras-98 cultivar with $45.20 \mathrm{~cm}$. In 2016, the plant height average values ranged from 56.16 to $70.53 \mathrm{~cm}$. The highest plant height values $(70.53 \mathrm{~cm})$ were obtained from $60.00 \mathrm{~kg} \mathrm{ha}^{-1}$ phosphorus dose applied to Aras-98 cultivar, $56.16 \mathrm{~cm}$ with the lowest value was obtained from parcels belonging to sugar- 90 cultivar of not phosphorous.

As shown in Table 2, plant height average values obtained from different zinc doses changed between $51.32-47.73 \mathrm{~cm}$ in 2015 and $67.82-60.26 \mathrm{~cm}$ in 2016 . In the first year of the experiment, the highest plant height value was obtained from Sugar-90 varieties with 54.07 $\mathrm{cm}$ and $25.00 \mathrm{~kg} \mathrm{ha}^{-1}$ zinc. The lowest value was determined in Aras-98 cultivar, which does not apply zinc dose, which is measured as $43.65 \mathrm{~cm}$.

The highest plant height $(56.22 \mathrm{~cm})$ value in the first year in terms of zinc $\mathrm{x}$ phosphorus doses applied in the research; It was obtained from $25.00 \mathrm{~kg} \mathrm{ha}^{-1}$ zinc $\times 60.00 \mathrm{~kg} \mathrm{ha}^{-1}$ phosphorus dose applied to Sugar-90 bean variety, and the lowest value was obtained from the P3 phosphorus dose and non-zinc parcels with $42.02 \mathrm{~cm}$ (Table 3).

\section{Number of Pods (number / plant)}

As seen in Table 4, there were differences in the number of pods in the experiment. In the first year of the experiment on the average number of pods; Interactions between year, variety, zinc doses, type $\mathrm{x}$ phosphorus and phosphorus $\mathrm{x}$ zinc dose interactions were significant, some $\mathrm{x}$ phosphorus $\mathrm{x}$ zinc doses were considered statistically insignificant. In the second year of the experiment, cultivar, zinc, phosphorus, $\mathrm{Zn} \times \mathrm{P}, \mathrm{C} \times \mathrm{x} \mathrm{Zn}$ and $\mathrm{C} \times \mathrm{Zn} \times \mathrm{P}$ interactions were found statistically significant.

Table 4. Averages and formed groups on number of pods in bean varieties*

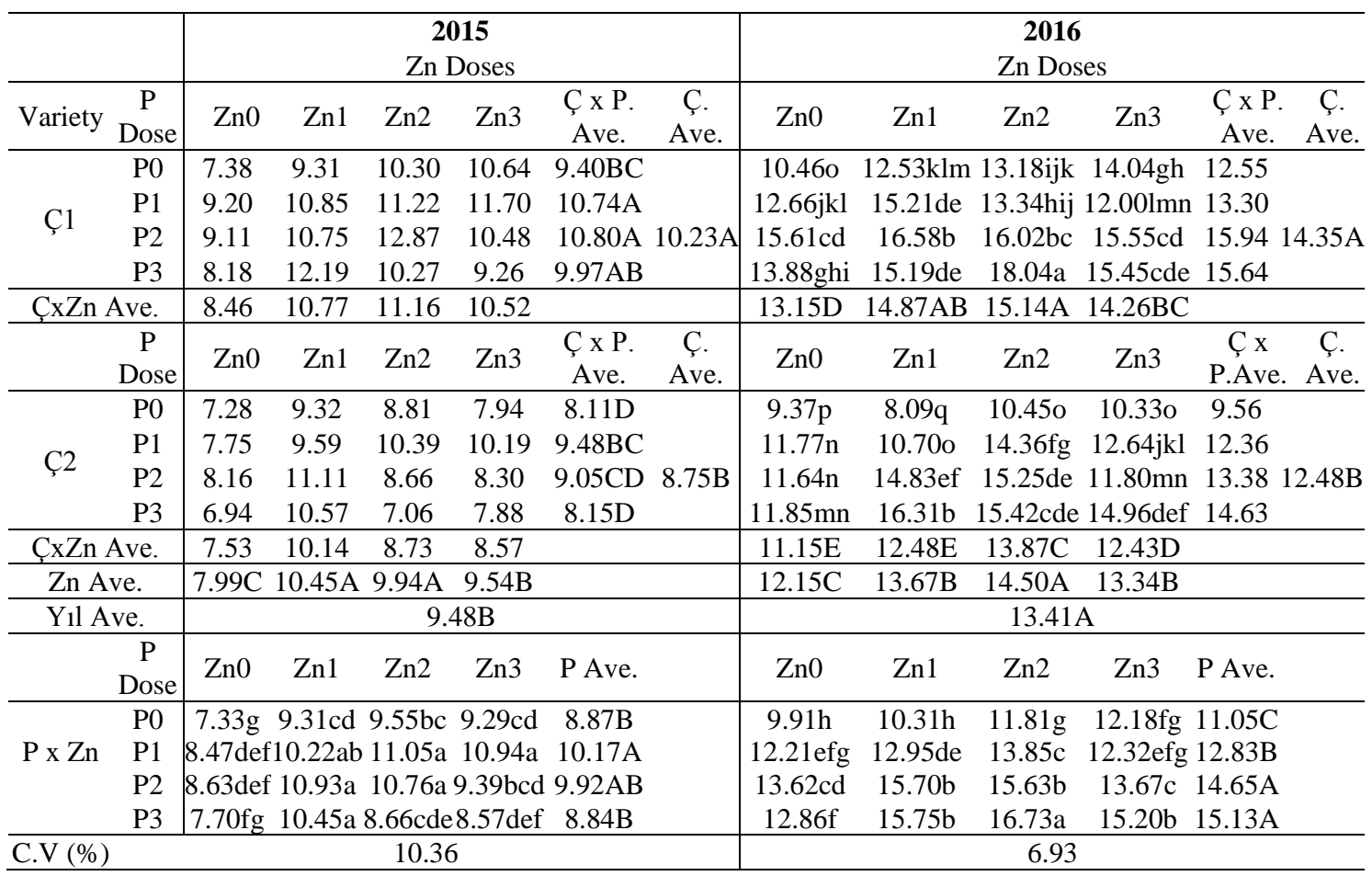

*The difference between the averages indicated with the same letters is not significant at $5 \%$; C.VCoefficient of variation. Zn- Zinc Dose; Ç1- Aras-98; Ç2-Sugar-90; P-Phosphorus doses; Ave.-

Average; Z x Zn- Variety x Zinc Dose Interaction; P x Zn- Phosphorus x Zinc Doses Interaction 
The average number of pods obtained at the end of the study was 9.48 in the first year and 13.41 in the second year. According to the results, the average number of pods per year was determined to be 10.21-14.35 in Seker-98 cultivar and 8.75-12.45 in Sugar-90 cultivar, respectively (Table 4). According to the data obtained, the interaction of the first year varieties $\mathrm{x}$ phosphorus doses on the average number of pods was statistically significant and the second year was insignificant. The highest number of pods was obtained from Aras-98 bean varieties with 10.8 pieces at 60.0 $\mathrm{kg} \mathrm{ha}^{-1}$ phosphorus dose, while the lowest value was obtained from $00.0 \mathrm{~kg} \mathrm{ha}^{-1}$ phosphorus dose in Sugar-90 cultivar with 8.11 pieces. According to these results, it was seen that increased phosphorus doses increased the number of pods in the plant up to a certain point. According to the data obtained at the end of the study, it was observed that the correlation was statistically significant on the average number of pods per day. The highest number of pods was obtained from $10.00 \mathrm{~kg} \mathrm{ha}^{-1}$ zinc and $40.00 \mathrm{~kg} \mathrm{ha}^{-1}$ phosphorus application per decare with $11.05 \mathrm{pcs}$ in the first year. The lowest value was obtained with 0.33 doses of both fertilizer doses. The highest number of pods obtained in the second year of the experiment was obtained from 16.73 number pods of $60.00 \mathrm{~kg} \mathrm{ha}^{-1}$ phosphorus and $10.00 \mathrm{~kg} \mathrm{ha}^{-1}$ zinc dose. The lowest value was found in 9 doses with 9.91 pieces (Table 4). According to the data obtained in the second year of the experiment, the interactions between the number of phosphorus $\mathrm{x}$ zinc doses considering the average number of pods were statistically significant and the first year was insignificant. The highest average number of pods was 18.04 and was obtained from $60.00 \mathrm{~kg} \mathrm{ha}^{-1}$ phosphorus and $10.00 \mathrm{~kg} \mathrm{ha}^{-1}$ zinc dose applied to Aras-98 bean cultivar. The lowest value was measured in the control parcel with Sugar-90 cultivar with 9.37 units (Table 4).

\section{Number of Branches (pieces / plant)}

In the study carried out in 2015-16 years, year, variety, phosphorus doses, variety $\mathrm{x}$ phosphorus doses and phosphorus $\mathrm{x}$ zinc doses interactions were found statistically significant considering the average number of branches in bean varieties in the first year. In the second year of the experiment, the effect of varieties on the average number of pods was found statistically significant (Table 5).

According to the results obtained in the experiment, the average number of branches in the first year was 4.33 and in the second year it was 5.24. The number of branches among the varieties were obtained from Aras-98 variety with 4.78-5.78 units, respectively. Sugar-90 varieties (3.88-4.70) branching was detected in a lower number (Table 5).

According to the results obtained, the first year on the number of branches was statistically significant and the second year was insignificant. According to the results obtained from the experiment, the highest average number of branches was obtained from the $40.00 \mathrm{~kg} \mathrm{ha}^{-1}$ phosphorus dose applied to the Aras -98 variety. The lowest value was obtained from the control (0 dose) of Sugar-90 variety with 3.59.

As seen in Table 5, the effect of $\mathrm{P} \times \mathrm{Zn}$ interaction on the average number of branches was found significant $(\mathrm{p}<0.01)$. The highest average number of branches was obtained from 4.67 pieces and $40.00 \mathrm{~kg} \mathrm{ha}^{-1}$ phosphorus $\mathrm{x} 10.00 \mathrm{~kg} \mathrm{ha}^{-1}$ zinc dose. The lowest value (3.89) was measured in the application of $60.00 \mathrm{~kg} \mathrm{ha}^{-1}$ phosphorus $\mathrm{x} 25.00 \mathrm{~kg} \mathrm{ha}^{-1}$ zinc dose. 
Table 5. Groups and averages of the number of branches in bean varieties*

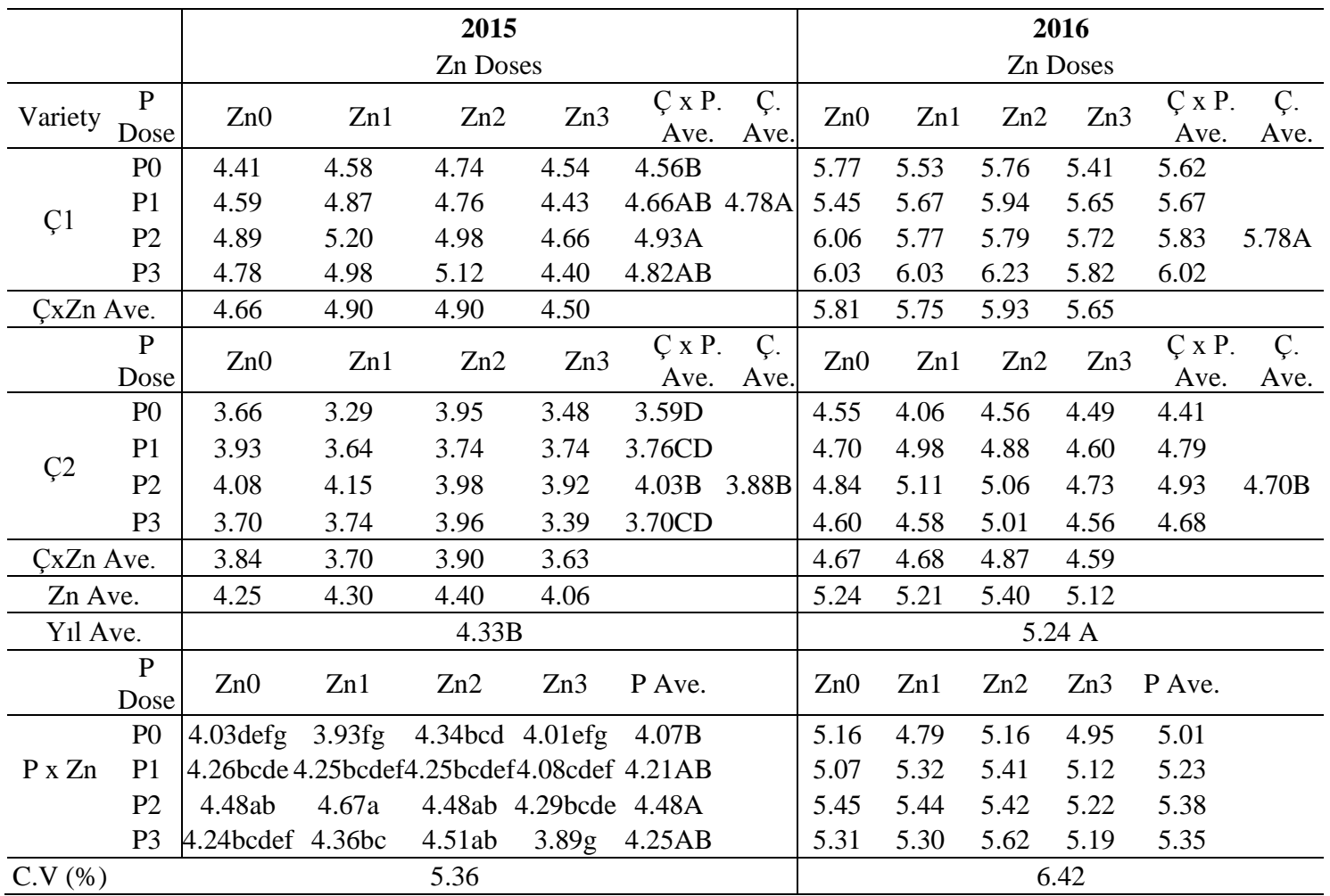

*The difference between the averages indicated with the same letters is not significant at $5 \%$; C.V-

Coefficient of variation. Zn- Zinc Dose; Ç1- Aras-98; Ç2-Sugar-90; P-Phosphorus doses; Ave.-

Average; Z x Zn- Variety x Zinc Dose Interaction; P x Zn- Phosphorus x Zinc Doses Interaction

\section{Harvest Index (\%)}

In the study conducted between 2015-16 years; It was statistically determined that other factors other than the varieties on the harvest index of zinc $\mathrm{x}$ phosphorus fertilizer application were insignificant (Table 6).

According to the results obtained in the study, the harvest index was found to be 41.89-41.91\% in the Aras-98 variety and 45.67-46.18 \% in the Ç2 (Şeker-90). In this study; phosphorus and zinc fertilizer doses were not found to be very effective on the harvest index. Harvest index = Grain / Plant stalk ratio is calculated with the formula.

\section{Grain Yield (kg ha-1)}

In 2015 and 2016, the effect on average grain yield of different phosphorus and zinc doses in dry bean varieties year, variety, phosphorus, zinc, variety x phosphorus, variety $\mathrm{x}$ zinc, phosphorus $\mathrm{x}$ zinc and cultivar $\mathrm{x}$ phosphorus $\mathrm{x}$ zinc interactions were found statistically significant (Table 7). The mean grain yields obtained at the end of the experiment were $2320.71 \mathrm{~kg} \mathrm{ha}^{-1}$ in the first year and $2518.90 \mathrm{~kg} \mathrm{ha}^{-1}$ in the second year.

According to the data, the average grain yield of Aras-98 bean varieties was $1449.80-2174.40 \mathrm{~kg} \mathrm{ha}^{-1}$ in years, and in Sugar-90 variety $2308.70-2863.00 \mathrm{~kg} \mathrm{ha}^{-1}$ (Das et al., 2005) in the study carried out in Erzurum. The yield of Yakutiye-98 and Aras-98 varieties were determined as 1842.00 and $1944.00 \mathrm{~kg} \mathrm{ha}^{-1}$, respectively. The effect of 
phosphorous fertilizer on average grain yield in beans was found statistically significant. The highest grain yield in both years of the experiment was obtained from a dose of $60.00 \mathrm{~kg} \mathrm{ha}^{-1}$ phosphorus in Sugar-90 cultivar with $2465.10-3468.50 \mathrm{~kg} \mathrm{ha}^{-1}$, respectively. The lowest value is determined as $1209.80-2000.00 \mathrm{~kg} \mathrm{ha}^{-1}$ in parcels with no fertilizer (Table 7). In parallel with the increasing phosphorus doses, the average grain yield of the varieties was increased up to $60.00 \mathrm{~kg} \mathrm{ha}^{-1}$ phosphorus dose and the yields of grain decreased.

Table 6. Groups and averages of harvest index in bean varieties*

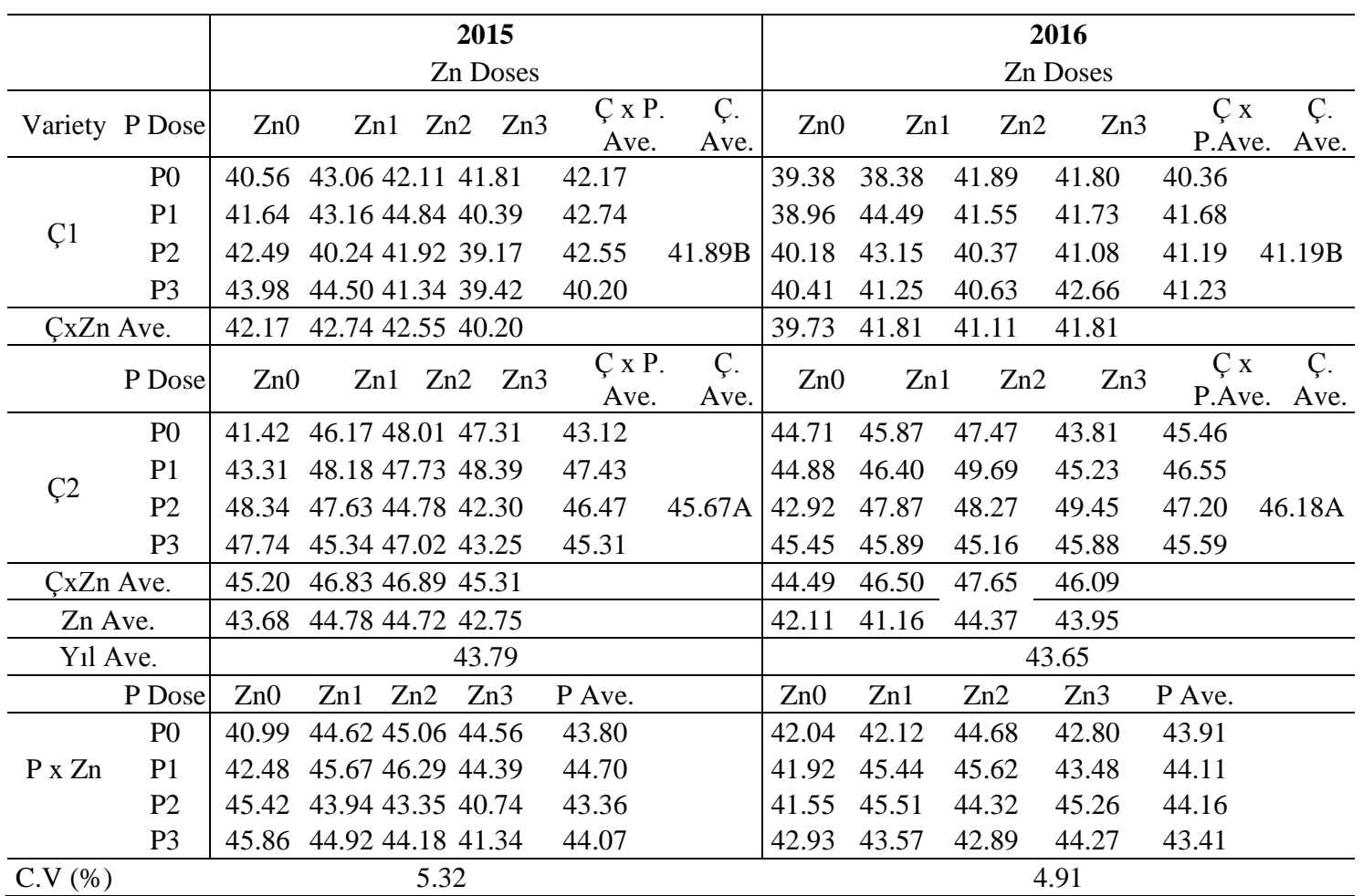

*The difference between the averages indicated with the same letters is not significant at 5\%. ; C.VCoefficient of variation. Zn- Zinc Dose; Ç1- Aras-98; Ç2-Sugar-90; P-Phosphorus doses; Ave.Average; Z x Zn- Variety x Zinc Dose Interaction; P x Zn- Phosphorus x Zinc Doses Interaction

As shown in Table 7, the effect of zinc doses on average grain yields in bean varieties was found significant. The highest grain yields obtained from the experiment were obtained from the application of 2340.00-4416.60 kg ha-1 and $25.00 \mathrm{~kg} \mathrm{ha}^{-1}$ zinc dose in Sugar-90 bean cultivar by years. The highest grain yields obtained from the experiment were obtained from the application of $2340.00-4416.60 \mathrm{~kg} \mathrm{ha}^{-1}$ and $25.00 \mathrm{~kg}$ $\mathrm{ha}^{-1}$ zinc dose in Sugar-90 bean cultivar by years.

The effect of phosphorus and zinc on the average grain yield in beans was found significant $(\mathrm{p}<0.01)$. The highest average grain yield was obtained in 2548.80-3304.80 kg ha-1 and $60 \mathrm{~kg} \mathrm{ha}^{-1}$ phosphorus and $25.00 \mathrm{~kg} \mathrm{ha}^{-1}$ zinc in both years of the experiment. The lowest value was obtained from the fertilizer-free parcels with $1425.50 \mathrm{~kg} \mathrm{ha}^{-1}$ in the first year and from the parcel applied $40.00 \mathrm{~kg} \mathrm{ha}^{-1}$ phosphorus in the second year (Table 7).

The effect of phosphorus and zinc fertilizer doses on mean grain evolution was found statistically significant. The highest average grain yield was obtained from the Sugar-90 
cultivar in both years of the experiment with $3380.00-4257.00 \mathrm{~kg} \mathrm{ha}^{-1}$ and $40.00 \mathrm{~kg}$ ha-1 phosphorus (P2) x $10.00 \mathrm{~kg} \mathrm{ha}^{-1}$ zinc ( $\mathrm{Zn}$ ) respectively, the lowest values were 1014.50$1484.70 \mathrm{~kg} \mathrm{ha}^{-1}$ Aras-98 cultivars were obtained from fertilizer applications (Table 7).

Table 7. Groups and averages of grain yield in bean varieties*

\begin{tabular}{|c|c|c|c|c|c|c|c|}
\hline \multirow[b]{2}{*}{ Variety } & \multirow[b]{2}{*}{$\begin{array}{c}\mathrm{P} \\
\text { Dose }\end{array}$} & \multicolumn{5}{|c|}{$\begin{array}{c}\mathbf{2 0 1 5} \\
\text { Zn Doses }\end{array}$} & $\begin{array}{c}\mathbf{2 0 1 6} \\
\text { Zn Doses }\end{array}$ \\
\hline & & $\mathrm{Zn} 0$ & $\mathrm{Zn} 1$ & $\mathrm{Zn} 2$ & $\mathrm{Zn} 3$ & $\begin{array}{l}\text { Ç x P. Ç. Ave. } \\
\text { Ave. }\end{array}$ & $\begin{array}{lllll}\mathrm{Zn} 1 & \mathrm{Zn} 2 & \mathrm{Zn} 3 & \begin{array}{c}\text { Çx P. } \\
\text { Ave. }\end{array} & \text { Ç. Ave. }\end{array}$ \\
\hline \multirow{4}{*}{ Ç1 } & P0 & $101.45 \mathrm{w}$ & $127.49 \mathrm{j}$ & $128.00 \mathrm{j}$ & $127.00 \mathrm{j}$ & $120.98 \mathrm{E}$ & $148.47 \mathrm{z} \quad 229.98 \mathrm{~s} 167.22 \mathrm{z} 255.70 \mathrm{n} 200.34 \mathrm{CD}$ \\
\hline & $\mathrm{P} 1$ & $138.34 \mathrm{~s}$ & $145.76 \mathrm{~h}$ & $146.76 \mathrm{gh}$ & $147.76 \mathrm{gh}$ & $144.65 \mathrm{CD}$ & $203.70 x \quad 242.42 p 215.04 v$ 222.68u $220.96 \mathrm{C}$ \\
\hline & $\mathrm{P} 2$ & 148.22qh & $167.50 \mathrm{e}$ & $171.77 n$ & $169.70 \mathrm{e}$ & $164.31 \mathrm{C} 144.98 \mathrm{~B}$ & $212.70 \mathrm{v} 229.30 \mathrm{st} 235.26 \mathrm{r} 193.96 \mathrm{y} 217.80 \mathrm{C} 217.44 \mathrm{~B}$ \\
\hline & P3 & $139.33 \mathrm{i}$ & $151.20 \mathrm{f}$ & $156.40 \mathrm{f}$ & $153.00 \mathrm{f}$ & $149.98 \mathrm{CD}$ & $251.66 \mathrm{o} \quad 227.06 \mathrm{t} 238.32 \mathrm{q} 206.34 \mathrm{w} 230.84 \mathrm{BC}$ \\
\hline \multicolumn{2}{|c|}{ Ç x Zn Ave. } & \multicolumn{2}{|c|}{$131.84 \mathrm{C} 147.98 \mathrm{~B}$} & \multicolumn{3}{|c|}{$150.73 \mathrm{~A} 149.38 \mathrm{~B}$} & $\begin{array}{cc}204.13 E & \begin{array}{c}232.19 \\
D\end{array}\end{array} 213.96 \mathrm{D} 219.67 \mathrm{D}$ \\
\hline & $\begin{array}{c}\mathrm{P} \\
\text { Dose }\end{array}$ & $\mathrm{Zn} 0$ & Zn1 & $\mathrm{Zn} 2$ & $\mathrm{Zn} 3$ & $\begin{array}{l}\text { Ç x P. Ç. Ave. } \\
\text { Ave. }\end{array}$ & $\begin{array}{llllll}\text { Zn0 } & \text { Zn1 Zn2 } & \text { Zn3 } & \begin{array}{c}\text { Ç x P. } \\
\text { Ave. }\end{array} & \text { Ç. Ave. } \\
\end{array}$ \\
\hline \multirow{4}{*}{ Ç2 } & $\mathrm{P} 0$ & $127.49 \mathrm{j}$ & $127.20 \mathrm{j}$ & $318.58 \mathrm{c}$ & $318.20 \mathrm{c}$ & $222.86 \mathrm{~B}$ & $286.59 \mathrm{k} \quad 305.47 \mathrm{~h} 352.90 \mathrm{c} 239.62 \mathrm{q} 221.14 \mathrm{BC}$ \\
\hline & $\mathrm{P} 1$ & $146.76 \mathrm{gh}$ & $146.00 \mathrm{~h}$ & $336.48 \mathrm{a}$ & $336.40 \mathrm{a}$ & $241.60 \mathrm{~A}$ & $192.63 y \quad 320.40 \mathrm{e} 326.07 \mathrm{~d} 278.23 \mathrm{~m} 279.33 \mathrm{~B}$ \\
\hline & $\mathrm{P} 2$ & $150.25 \mathrm{fg}$ & $169.77 \mathrm{e}$ & $338.00 \mathrm{a}$ & $328.03 b$ & $246.51 \mathrm{~A} 230.87 \mathrm{~A}$ & $307.63 \mathrm{~g} \quad 370.79 \mathrm{~b} 425.70 \mathrm{a} \quad 283.301 \quad 346.85 \mathrm{~A} \quad 286.30 \mathrm{~A}$ \\
\hline & P3 & $135.20 \mathrm{i}$ & $151.20 \mathrm{f}$ & $282.75 \mathrm{~d}$ & $281.00 \mathrm{~d}$ & $212.53 \mathrm{~B}$ & $284.141 \quad 314.06 \mathrm{f} 301.97 \mathrm{i} \quad 291.39 \mathrm{j} 297.89 \mathrm{AB}$ \\
\hline \multicolumn{2}{|c|}{ Ç x Zn Ave. } & 139.92B & 148.54B & $318.95 \mathrm{~A}$ & $315.90 \mathrm{~A}$ & & 267.74C 327.68B351.66A 273.13C \\
\hline \multicolumn{2}{|c|}{ Zn Ave. } & $135.88 \mathrm{C}$ & 148.26B & $234.84 \mathrm{~A}$ & $232.64 \mathrm{~A}$ & & $235.93 \mathrm{C} 279.93 \mathrm{~A} 282.81 \mathrm{~A} 246.40 \mathrm{~B}$ \\
\hline \multicolumn{2}{|c|}{ Year Ave. } & \multicolumn{5}{|c|}{$232.71 \mathrm{~B}$} & $251.89 \mathrm{~A}$ \\
\hline & \begin{tabular}{c|}
$\mathrm{P}$ \\
Dose
\end{tabular} & $\mathrm{Zn} 0$ & Zn1 & $\mathrm{Zn} 2$ & Zn3 & P Ave. & Zn1 Zn2 Zn3 P Ave. \\
\hline \multirow{4}{*}{$\mathrm{P} \times \mathrm{Zn}$} & P0 & $114.47 \mathrm{~m}$ & 127.341 & $223.29 \mathrm{~d}$ & 222.60de & e $171.92 \mathrm{C}$ & $217.53 \mathrm{j} \quad 267.72 \mathrm{e} 260.06 \mathrm{e} 247.66 \mathrm{~h} \quad 248.24 \mathrm{~B}$ \\
\hline & P1 & $142.55 \mathrm{j}$ & $145.88 \mathrm{ij}$ & j $241.62 c$ & $242.08 \mathrm{c}$ & $193.03 \mathrm{~A}$ & 198.16k 281.41c 270.55d 250.45g 250.14B \\
\hline & $\mathrm{P} 2$ & $149.23 \mathrm{hi}$ & $168.63 \mathrm{~g}$ & $254.88 \mathrm{a}$ & $248.86 b$ & $205.40 \mathrm{~A}$ & $260.16 \mathrm{f} \quad 300.04 \mathrm{~b} 330.48 \mathrm{a} \quad 238.63 \mathrm{i} \quad 282.32 \mathrm{~A}$ \\
\hline & P3 & $137.26 \mathrm{k}$ & $151.20 \mathrm{~h}$ & $219.57 \mathrm{ef}$ & $217.00 \mathrm{f}$ & f $181.25 \mathrm{~B}$ & $267.90 \mathrm{e} \quad 270.56 \mathrm{~d} 270.14 \mathrm{~d} 248.86 \mathrm{gh} 264.36 \mathrm{~B}$ \\
\hline \multicolumn{2}{|l|}{ C.V (\%) } & \multicolumn{5}{|c|}{7.01} & 4.83 \\
\hline
\end{tabular}

\section{Crude Protein Content (\%)}

At the end of the study, it was found that the effects of type $\mathrm{x}$ zinc and phosphorus $\mathrm{x}$ zinc doses on the crude protein content were statistically significant. As of years, the protein ratio was obtained from Seker-90 variety with 22.48-12.08\%, respectively. Lower crude protein ratios were obtained from Aras-98 variety (22.45-22.04\%) (Table $8)$.

The effect of different zinc doses on average crude protein ratios was found statistically significant in every two years when seen in Table 8 . The highest crude protein content (24.20-23.96\%) was obtained from Sugar-90 bean cultivars of $25.00 \mathrm{~kg}$ $\mathrm{ha}^{-1}$ zinc fertilizer while the lowest values $(20.95-21.79 \%)$ were obtained from the fertilizer application of the same type.

The effect of phosphorus doses on the average crude protein ratio was found significant $(\mathrm{p}<0.01$ ). The highest values were obtained from 23.56 to $23.26 \%$ crude protein ratios and $60.00 \mathrm{~kg} \mathrm{ha}^{-1}$ phosphorus dose in 2015-2016. The lowest value was 
found in the first year without fertilizer with a rate of $21.23 \%$ and with a rate of $80.00 \mathrm{~kg} \mathrm{ha}^{-1}$ phosphorus with $21.98 \%$ in the second year (Table 8 ).

Table 8. Groups and averages of crude protein ratios in bean varieties*

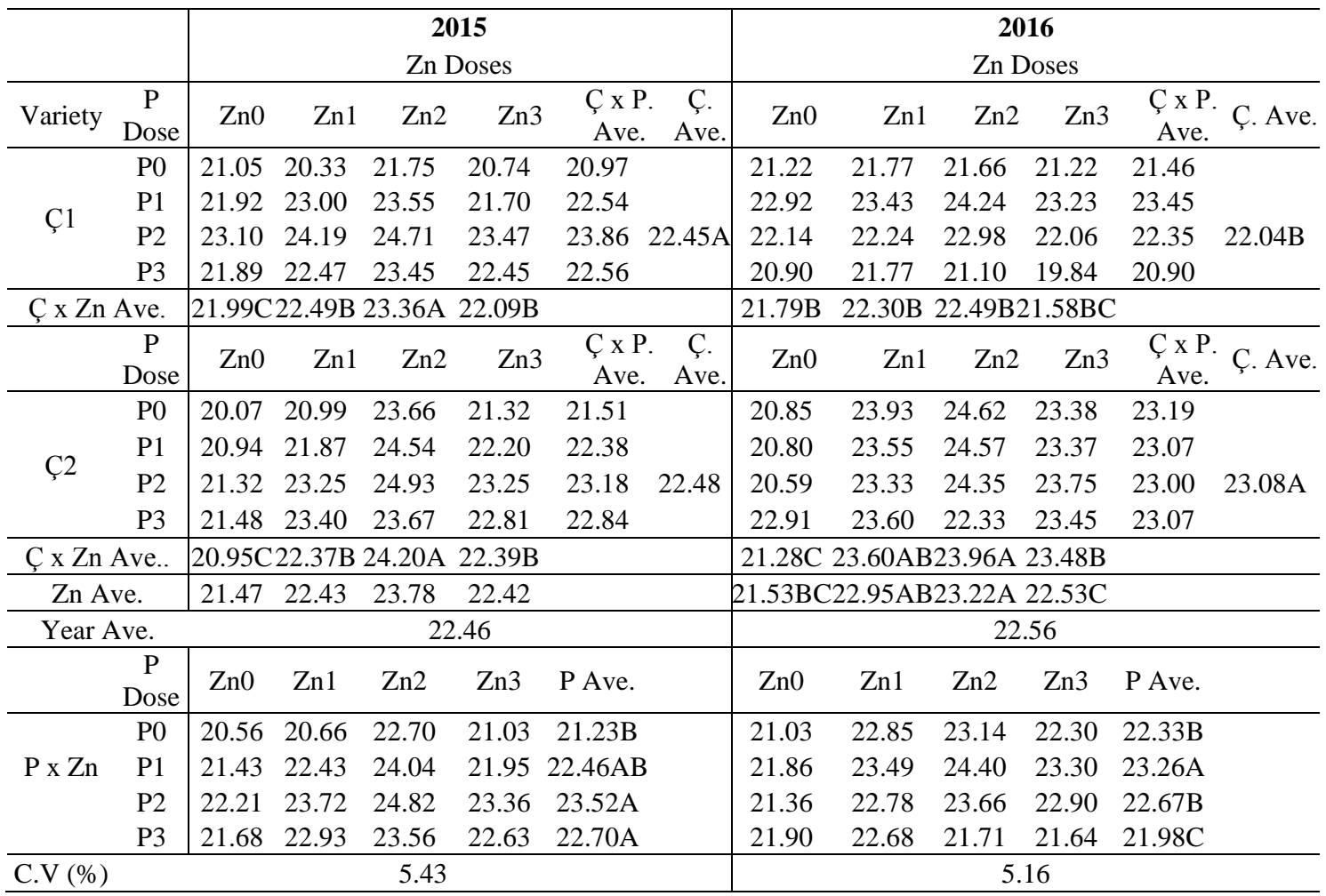

*The difference between the averages indicated with the same letters is not significant at $5 \%$; C.VCoefficient of variation. Zn- Zinc Dose; Ç1- Aras-98; Ç2-Sugar-90; P-Phosphorus doses; Ave.-

Average; Z x Zn- Variety x Zinc Dose Interaction; P x Zn- Phosphorus x Zinc Doses Interaction

\section{Discussion}

These results of plant height values in the second year were significantly higher than the first year. In the first trial year, due to lack of precipitation, the decrease in the plant output and the decrease in the time between the output and the maturation caused the plant height values to decrease. This difference is thought to be caused by the climate in terms of plant height values (Elkoca and Kantar, 2003). This difference between years is thought to be due to the effect of climate factors as well as phosphorus fertilizer applied. It is stated that phosphorus, like nitrogen, increases the root, stem length, seed production, seed quality and resistance to diseases (Marschner, 1995; Hussein and Alva, 2014). Many research studies (Shrotriya, 1998; Bokhtiar and Sakurai, 2005; Pholsen and Sormsungnoen, 2005; Bayu et al., 2006; Barros et al., 2007; Alatürk, 2012) on fertilization obtained similar results as this study. In similar studies, increased fertilization of leguminous crops indicated that zinc fertilization increased plant height (Sing and Saxena, 1986; Togay and Anlarsal, 2008). In the second year of the experiment, the interaction effect between doses was statistically insignificant. In similar studies Tisdale and Nelson (1966), reported that phosphorous fertilizers added to phosphorous-rich soils make it difficult for the plants to uptake other nutrients, especially zinc, resulting in zinc deficiency in the plants grown in these parcels. 
Similarly, Bayraktar (1966) also stated that when excess phosphorus is present in the soil or when more phosphorus is supplied to the plant, excess phosphorus prevents the extraction of 67 micro elements such as zinc and iron.

In a similar study conducted by Elkoca and Kantar (2004), the number of pods ranged from 3.5-4.2, indicating that this feature showed a wide variation according to the types and lines. Legumes in plants are the most effective group of phosphorus in the soil (Altın et al., 2005; Batica et al., 2017). Turunko and Mohammed (2014), in Ethiopia's Arbe Minch agricultural enterprise using Red Wolaita varieties; 5 different doses of phosphorus $\left(00.00,10.00,20.00,30.00,40.00 \mathrm{~kg} \mathrm{ha}^{-1}\right)$ growth, dry matter and yield components were investigated. As a result, the most suitable phosphorus fertilizer dose was $20.00 \mathrm{~kg} \mathrm{ha}^{-1}$. In another similar study, it was noted that the leaf area of beans increased significantly with the increase of phosphorus dose from $25.00 \mathrm{~kg}$ ha- $^{1}$ to $75.00 \mathrm{~kg} \mathrm{ha}^{-1}$ (Veeresh, 2003). According to these results, increasing doses of phosphorus in low zinc doses caused increases in the number of pods up to a certain point. Lonergan et al. (1982) obtained higher yields than plants in low $\mathrm{Zn}$ and high $\mathrm{P}$ conditions. In contrast, an antagonist effect also occured, resulting in reduced yields (Ozanne, 1980). As the reason for these results; Besides to the environment and genotype, high doses of phosphorous fertilizers are thought to result in yield losses due to reduced zinc uptake (Ozanne, 1980).

Unlike nitrogenous fertilizers, the effect of phosphorus fertilizers remains limited on the number of branches depending on the environment and genetic structure. It is thought that this difference in average number of branches due to years is due to insufficient quantity and distribution of rainfall in the first year as well as genetic factors (Elkoca and Kantar, 2003). Like the number of pods, the number of branches also show a very wide variation depending on the variety and lines (Elkoca and Kantar, 2004). In spite of increasing doses of phosphorus, it is thought that zinc use efficiency and number of branches decrease (Ozanne, 1980).

In the studies conducted by some researchers, it has been observed that these effects vary widely. It is thought that this difference is caused by environment, genotype and cultural practices. Gangwar and Singh (1986) showed in their study, that the rate of harvest index of zinc fertilizers increased the maximum rate of foliar applied fertilizers. Azad et al. (1993), reported that zinc fertilizers increased the rate of harvest index up to a certain dose and then decreased. In this study, it is observed that zinc fertilizer increased the ratio of harvest index by 15.00 and $30.00 \mathrm{~kg} \mathrm{ha}^{-1}$ and then it started to decrease.

Climate factors are undoubtedly the most important factors in determining the fate of agricultural production. It is thought that this difference between years is mainly due to the fact that the precipitation amount $(43.6 \mathrm{~mm})$ and distribution in the first year is lower and insufficient compared to the second year $(73.33 \mathrm{~mm})$ (Table 1). The balance of soil water in beans is very sensitive to flowering period. Fluctuations in this period are reported to cause 20\% yield losses in yields (Elkoca and Kantar, 2003). In the second year fertilizer doses were used more effectively with rainfall in the development periods of the plant. In the first year, the average temperature were recorded higher than in the second year, especially in flowering and pollination periods of the plant in other developmental according to the periods.

The grain yield in beans is dependent on other genetic-based variations, particularly earliness in various environmental conditions (Dreyer and Wielpütz, 1998). Similar studies have shown that phosphorus promotes flowering and pod formation in the plant 
(Araújo et al., 2000). In the experiment, it can be said that the difference between the first year and the second year zinc doses was due to the fact that the phosphorus in the first year inhibited the uptake of zinc more than in the second year. In the second year, it is thought that the climate is more suitable and fertilizers may be taken more uniformly (Toğay and Anlarsal, 2007). In many studies, it has been reported that phosphorus and zinc fertilizers are used together and that the efficiency of phosphorus zinc decreases the efficiency and quality decreases (Ozanne, 1980; Lonergan et al., 1982). In a similar study, it was reported that environmental and genetic factors were effective on the average grain yield in lentils (Islam et al., 1989).

Many previous studies have shown that the protein content of beans varies between $17.40 \%$ and $28.00 \%$. It has been reported that bacterial applications, especially nitrogen fertilization, increase this rate (Tajini et al., 2012; Bulut, 2013; Özturan and Akman, 2017). The effect of zinc fertilizer on crude protein content was found to be important due to environmental and genotypic factors. Similar results were obtained in other studies conducted on legumes (Toğay and Anlarsal, 2008). Zinc is an active element in biochemical events and has a biological interaction. When used in combination with phosphorus, a decrease in the uptake by plants occurs. The most important element limiting the use efficiency of zinc by plants is phosphorus. Especially in the case of phosphorus poor soils, where the need for excess phosphorus is met, the use of zinc decreases. Disruptions in phosphorus and zinc balance in the plant cause disruptions in the cell and some parts of the cell (Das et al., 2005; Khorgamy and Farnis, 2009; Salimpour et al., 2010).

\section{Conclusion}

In this study carried out in Van-Gevaş, the effect of different phosphorus and zinc doses on the yield and yield components of dry bean varieties were investigated. Although these factors have changed over the years, they have provided important information about yield and yield components. The results of the decrease in zinc utilization efficiency in high phosphorus doses have emerged in yield and quality parameters. Especially in our city where zinc deficiency is seen too much, and especially before planting other plants, soil analysis should be conducted before planting. In view of these results, phosphorus fertilization should be done between $10.00-30.00 \mathrm{~kg} \mathrm{ha}^{-1}$ zinc and $20.00-80.00 \mathrm{~kg} \mathrm{ha}^{-1}$. The grain yield which is close to Turkey's on average or above on a yearly basis may be interrelated with zinc and phosphorus deficiency in the soil, which is thought to reduce the yield and quality losses.

\section{REFERENCES}

[1] Adak, M. S., Güler, M., Kayan, N. (2010): Possibilities to increase the production of edible legumes. - Türkiye Ziraat Mühendisliği VII. Teknik Kongresi, Ankara: 329-341. (in Turkish).

[2] Adak, M. S. (2014): The importance of edible beans in Turkey, production and monitoring policies. - Tarım ve Mühendislik 103: 24-30. (in Turkish).

[3] Alatürk, F. (2012): The effects of fertilization on yield and chemical composition of Çanakkale province and pastures. - Master's Thesis, Çanakkale Onsekiz Mart 
Üniversitesi, Fen Bilimleri Enstitüsü. Tarla Bitkileri Anabilim Dalı, Çanakkale. (in Turkish).

[4] Altın, M., Gökkuş, A., Koç, A. (2005): Breeding of meadow pasture plants. - TKB, TÜGEM, Çayır-Mera Yem Bitkileri ve Havza Geliştirme Daire Başkanlığı, Ankara, 468p. (in Turkish).

[5] Altunkaynak, Ö. A. (2018): Effects of different nitrogen doses and bacterial vaccination on grain yield and yield characteristics in bean (Phaseolus vulgaris L.). - Selcuk Üniversitesi Fen Bilimleri Enstitüsü, Yüksek Lisans Tezi, 35p. Konya. (in Turkish).

[6] Araújo, A. P., Teixeira, M. G., De Almeida, D. L. (2000): Growth and yield of common bean cultivars at two soil phosporus leves under biological nitrogen fixation. - Pesg. Agropec. Bras. 35(4).

[7] Arıoğlu, H. (1989): Yağ bitkileri (Soya ve Yerfıstığı). - Çukurova Üni. Ziraat Fak. Ders Kitab1, No.35.

[8] Azad, A. S., Manchada, J. S., Gill, A. S., Bains, S. S. (1993): Effect of zinc application on grain yield, yield components and nutrient content of lentil. - Lens Newsletter 20(2): 3033.

[9] Barros, I., Gaiser, T., Lange, F. M., Römheld, V. (2007): Mineral nutrition and water usepatterns of a maize/cowpea intercrop on a highly acidic soil of the tropic semiarid. Field Crops Research 101: 26-36.

[10] Batıca, M., Alatürk, F., Gökkuş, A. (2017): The effect of fertilization on the yield and some Properties of chewing gum (Cyamopsis tetragonoloba L. Taub.). - Türk Tarım ve Doğa Bilimleri Dergisi 4(1): 79-87. (in Turkish).

[11] Bayraktar, K. (1966): Vegetable growing. - Ege Üniversitesi Ziraat Fakültesi Yayınları 1: 144-160.

[12] Bayu, W., Rethman, N. F. G., Hammes, P. S., Alemu, G. (2006): Effects of farmyard manure and norganic fertilizers on sorghum growth, yield, and nitrogen use in a SemiArid Area of Ethiopia. - Journal of Plant Nutrition 29: 391-407.

[13] Bokhtiar, S. M., Sakurai, K. (2005): Effect of application of inorganic and organic fertilizers on growth, yield and quality of sugarcane. - Sugar Tech. 7: 35-37.

[14] Bulut, N. (2013): Effect of organic fertilizers on yield and yield components in bean (Phaseolus vulgaris L.) in grafted ungrafted conditions. - Yüzüncü Y1l Üniversitesi, Fen Bilimleri Enstitüsü (Yüksek Lisans), Van, 47. (in Turkish).

[15] Ceylan, A., Sepetoğlu, H. (1979): Lentil (Lens culinaris Medic.) Sowing Frequency Research. - E.Ü. Ziraat Fak. Dergisi, Cilt: 25(2). (in Turkish).

[16] Das, K., Dang, R., Shivananda, T. N., Sur, P. (2005): Interaction between phosphorus and zinc on the biomass yield and yield attributes of the medicinal plant stevia (Stevia rebaudiana). - Science World Journal 5: 390-395.

[17] Dreyer, S., Wielpütz, J. (1998): Cultivar trials with bush beans. - Gemüse (München) 34(6): 359-361.

[18] Düzgüneş, O., Kesici, T., Koyuncu, O., Gürbüz, F. (1987): Research and experiment methods. - A.Ü. Ziraat Fakültesi Yayınları: 1021 Ders Kitabı: 295. S.381. (in Turkish).

[19] Elkoca, E., Kantar, F. (2003): Determination of early and high yield bean (Phaseolus vulgaris L.) genotypes suitable for Erzurum ecological conditions. - Atatürk Üniversitesi Ziraat Fakültesi Dergisi 35(4): 137-142.

[20] Elkoca, E., Kantar, F. (2004): Erzurum ekolojik koşullarına uygun erkenci ve yüksek verimli kuru fasulye (Phaseolus vulgaris L.) genotiplerinin belirlenmesi. - Atatürk Üniversitesi Ziraat Fakültesi Dergisi 35(3-4): 137-142.

[21] Engin, M. (1989): Yemeklik dane baklagiller. - Ç.Ü. Ziraat Fakültesi Yayınları, Ders Kitabı: 110. ÇÜ Basımevi Adana.

[22] FAO. (2015): Tarımsal İstatistikler. - http://faostat3.fao.org/browse/Q/QC/E. (Erişim Tarihi: 13.05.2019).

[23] Gangwar, K. S., Singh, N. P. (1986): Effect of zinc application on yield and quality of lentil (Lens culinaris Medic.). - Legume Research 11(1): 11-14. 
[24] Hussein, M. M., Alva, A. K. (2014): Growth, yield and water use efficiency of forage sorghum as affected by NPK fertilizer and deficit irrigation. - American Journal of Plant Sciences 5: 2134-2140.

[25] Islam, M. S., Bhuriya, M. S., Mich, M. G. (1989): Effect of zinc on lentil yield and yield components. - Lens Newsletter 16(1): 30-32.

[26] Khorgamy, A., Farnia, A. (2009): Effect of phosphorus and zinc fertilisation on yield and yield components of chick pea cultivars. - African Crop Science Conference Proceedings 9: 205-208.

[27] Loneragan, J. F., Grunes, D. L., Welch, R. M., Aduayi, E. A., Tengah, A., Lazar, V. A., Cary, E. E. (1982): Phosphorus accumulation and toxicity in leaves in relation to zinc supply. - Soil Science Soc. Am. J. 46: 345-352.

[28] McPhee, K. E., Muehlbauer, F. J. (2002): Improving the nutritional value of cool season food legumes. - Journal of Crop Production 5(1-2): 191-211.

[29] Olsen, S. R., Dean, L. A. (1965): Phosphorus of sail analysis. Part. 2. - Ag1on. 9. Amer. Sac. of Agr. Inc. Publisher. Madison, Wisconsin U. S. A.

[30] Ozanne, P. G. (1980): Phosphate nutrition of plants - a general treatise. - American Society of Agronomy: 559-589.

[31] Özturan Akman, Y. (2017): Rhizobium and mycorrhiza applications of beans (Phaseolus)vulgaris L.) on grain yield and some agricultural characteristics. - Ondokuz Mayıs Üniversitesi, Fen Bilimleri Enstitüsü (Yüksek Lisans), Samsun, 155. (in Turkish).

[32] Pekşen, E., Artık, C. (2005): Anti-besinsel maddeler ve yemeklik tane baklagillerin besleyici değerleri. - Ondokuz Mayıs Üniversitesi Ziraat Fakültesi Dergisi 20(2): 110120.

[33] Salimpour, S., Khavazi, K., Nadian, H., Besharati, H., Miransari, M. (2010): Enhancingphosphorous availability to canola (Brassica napus L.) using P solubilizing and sulfur oxidizing bacteria. - Australian Journal of Crop Science 4(5): 330-334.

[34] Shrotriya, G. C. (1998): Balanced fertilizer-India experience. - Proceedings of Symposium on Plant Nutrition Management for Sustainable Agricultural Growth, NFDC, 8-10 December 1997, Islamabad.

[35] Sing, K. N., Bali, A. S., Ganai, B. A., Hasan, B. (1994): Optimum Spacing and Seed Rate for Lentil (Lens culinaris Medic.) in Casmir. - Indian Journal of Agricultural Sciences 64(6): 392-393.

[36] Singh, N. P., Saxena, M. C. (1986): Response of Lentil to Phosphorus and Zinc Application. - Lens Newsletter 13(2): 27-28.

[37] Şehirali, S. (1988): Legumes, edible. - A.Ü. Ziraat Fakültesi Yayınları, 1089, Ders Kitabı 314. (in Turkish).

[38] Tajini, F., Trabelsi, M., Drevon, J. (2012): Combined inoculation with glomusintraradices and rhizobium tropici CIAT 899 increases phosphorus use efficiency for symbiotic nitrogen fixation in common bean (Phaseolus vulgaris L.). - Saudi Journal of Biological Sciences 19: 157-163.

[39] Tisdale, S. L., Nelson, W. L. (1966): Soil Fertility and fertilizers. - Second edition. The MacmlHan Cd: Collier-MacmiUan Ltd, London. S: 239, 340.

[40] Togay, Y., Anlarsal, A. E. (2008): Different doses of zinc and phosphorus lentils (Lens culinaris Medic.) and its effect on yield components. - Yüzüncü Yıl Üniversitesi, Ziraat Fakültesi, Tarım Bilimleri Dergisi (J. Agric. Sci.) 18(1): 49-59. (in Turkish).

[41] TÜİK. (2018): Tarımsal İstatistikler. - http://www.tuik.gov.tr/PreTablo.do?alt_id=1001: (Erişim Tarihi: 13.05.2019).

[42] Turuko, M., Mohammed, A. (2014): Effect of different phosphorus fertilizer rates on growth, dry matter yield and yield components of common bean (Phaseolus vulgaris L.). - World Journal of Agricultural Research 2(3): 88-92.

[43] Veeresh, N. K. (2003): Response of French bean (Phaseolus vulgaris L.) to fertilizer levels in northern transitional zone of Karnataka. - M.Sc. Thesis, University of Agriculture Science Dharwad (India). 
[44] Yalçın, S. R., Usta, S. (1990): The effect of zinc application on the development of corn plant and zinc, iron, manganese and copper scopes. - A.Ü. Ziraat Fakültesi Yıllığ 41(12): 195-204. (in Turkish). 